to improve the operation of every machine encountered; his mental processes consisted in first gaining a thorough insight into the operation of the existent machine and then applying remedies to the weaknesses disclosed. This passion for improving and inventing continued to the end of his life. For example, during the last two years he had been working on an improved electrical tele-mechanism of great ingenuity.

In Catterson-Smith there was an unusual and happy blend of art and science. His artistic instincts called for craftsmanship and appropriateness, his scientific instincts for accuracy and efficiency. These qualities imbued all his work. In addition, he possessed a personality of great friendliness and charm. No wonder he gained the affection of all his students and colleagues.

W. H. ECCLES.

\section{Prof. James Muir}

By the death, on February 17, of Prof. James Muir, emeritus professor of natural philosophy in the Royal Technical College, Glasgow, there has passed a great teacher and a man singularly devoted to science and to the quest of knowledge for its own sake.

Dr. Muir was born in 1875, and his early interest in science was stimulated by his education at Allan Glen's School, Glasgow. On leaving school, he entered his father's business ; but the influence of his school training led him to consult Prof. James Blyth, on whose advice he entered his evening class at the Technical College. Thus began a connexion with that College which was to remain unbroken throughout his life.

Muir graduated B.Sc. in 1896 at the University of Glasgow, with special distinction in engineering and astronomy, and D.Sc. in 1902, having obtained the associateship of the College in mathematics and physics in 1897, in which year he was awarded an 1851 Exhibition Scholarship at Cambridge. His researches at Trinity College, under Prof. Ewing, into the effect of temperature on recovery from overstrain were published in the Proceedings of the Royal Society, and he was awarded the B.A. degree of Cambridge, followed in 1904 by the M.A. Returning to Glasgow, he became chief assistant to Prof. Blyth, and then assistant to Prof. Andrew Gray at the University of Glasgow.

In 1906, on the death of Prof. Blyth, Dr. Muir succeeded to the Freeland chair of natural philosophy in the Technical College, Glasgow, and he entered upon his duties with a boundless enthusiasm which continued during the thirty-two years which ended with his retirement in 1938.

Prof. Muir always gave foremost place to his teaching and to the interests of his large classes of day and evening students. Nevertheless, he found time to use to the full the resources of his department in conducting many valuable researches on behalf of the industrial firms of Glasgow, and during the War of 1914-18 these researches were directed to the service of the country. $\mathrm{He}$ willingly and enthusiastically entered into any movement for promoting the welfare of the College, such as the work of the College Research Journal and the re-arrangement and cataloguing of the founder's library.

Prof. Muir will always be remembered as a great teacher whose constant aim was to induce his students to think for themselves, to abhor anything slipshod and to enjoy hard work as he himself enjoyed it. The sincerity and love of truth shown in his scientific work was carried into his everyday life; 'he nothing common did or mean', nor could he compromise upon ethical principles. His students, like all his immediate colleagues, grew to look upon him with affectionate respect: they found him always approachable and eager to share and stimulate their interests. On his retirement, as an expression of their admiration and regard, his former students and colleagues founded and endowed the James Muir Prizes in natural philosophy, and presented to the College the fine portrait by David S. Ewart which now hangs in his old lecture room.

Dr. Muir's tastes were simple and his wants were few. From his student days he had a great love of the Scottish hills, and friends have most pleasant memories of holiday climbs in his company. At the time of his death he had prepared the manuscript of a text-book on physics and he was engaged on a memoir of the founder of the College. Prof. Muir was unmarried and is survived by three sisters.

\section{Mr. F. R. S. Balfour, C.V.O.}

By the death of Frederick Robert Stephen Balfour on February 2, arboriculturists and horticulturists have lost a valued friend and counsellor. Though primarily an arboriculturist he was also a keen naturalist and a true lover of all kinds of plants. He had the advantages of having the means of travelling and of inheriting from his mother the beautiful estate of Dawyck in Tweeddale which possessed a number of interesting and historical trees. In later life he had important business interests in the City of London, and it was probably his business ability which led him to include experimental forestry plots on a large scale at Dawyck.

Balfour was born on March 11, 1875, and was educated at Loretto and Trinity College, Oxford. In his early days he spent four years on the Pacific coast of North America, and, although he was greatly interested in all the plant and animal life, it was the trees which captivated his imagination. He was familiar also with the trees of eastern Canada and the north-eastern States and had a working knowledge of the wonderful forests of south Chile. He became, therefore, a recognized authority in Great Britain on American trees, especially conifers. When he returned to Scotland he developed the collection of North American trees at Dawyck, introducing several species for the first time, his favourite being the rare Picea Breweriana, and trying out practically every species which could be expected to survive. In addition to his New World conifers he had also a collection of the more hardy Asiatic species mostly introduced by E. H. Wilson, whose second expedition to China he helped to finance. He had a great knowledge of British birds and was proud of his notable collection of foreign ducks and pheasants. From the economic point of view his most important contribution to sylviculture concerned the trial of promising, but as yet unfamiliar, species under forestry conditions or on the mountainside.

Balfour's published communications are scattered throughout a number of journals; his account of David Douglas, his "History of Conifers in Scotland" which covered a wide field, and a paper read recently before the Linnean Society on Archibald Menzies being perhaps the most noteworthy.

As a member of the Home Grown Timber Com- 
mittee, Balfour was sent to France as liaison officer to the French Government during the War of 191418, with reference to the supplies of timber. He was one of the founders and remained a most active member of the Roads Beautifying Association, being at his death chairman of the technical sub-committee. His wide love of plants was shown by his zeal in supplying material for figuring in the Botanical Magazine.

Balfour had been a fellow of the Linnean Society for many years and had served on the Council of the Royal Horticultural Society, the latter bestowing on him in 1927 its highest award. $\mathrm{He}$ had been a member of the King's Bodyguard for Scotland since 1900 and was made C.V.O. in 1944. His other interests included history, architecture and music, he himself possessing a fine baritone voice. But no notice of him would be complete without emphasis on his exceptional courtesy and charm, which were due largely to his understanding and sympathy and to the genuine pleasure it gave him to do good to his fellow-man.

A. D. Cotron.

We regret to announce the following deaths:

Mr. F. Bligh Bond, formerly director of excavations at Glastonbury Abbey, on March 8, aged eighty.

Mr. G. V. Boys, secretary of the Institution of Naval Architects since 1935, on March 15, aged fifty-one.

Sir Thomas Lewis, C.B.E., F.R.S., physician-incharge of the Department of Clinical Research at University College Hospital, London, on March 17, aged sixty-three.

Mr. P. W. Paget, a technical assistant of Marconi during his early work in England from 1896 onwards.

Prof. Stanisław Zaremba, sometime professor of mathematics in the University of Cracow, and a member of the Polish Academy of Science, aged eighty-one.

\section{NEWS and VIEWS}

\section{Chair of Biochemistry at Sheffield:}

Prof. H. A. Krebs

THE University of Sheffield has conferred on Dr. H. A. Krebs the title and status of professor of biochemistry in recognition of his eminence in the world of science. Dr. Krebs was awarded the degree of M.D. (Hamburg) in 1925 and that of M.A. (Cambridge) in 1935. He held the post of research assistant at the Kaiser Wilhelm Institute for Biology, BerlinDahlem, during 1926-30 under Prof. Otto Warburg. After further experience in Germany he became a Rockefeller research student in the Biochemical Laboratory, Cambridge (1933-34), demonstrator in biochemistry at Cambridge (1934-35) and lecturer in pharmacology at Sheffield (1935-38). In 1938 he was appointed lecturer in charge of the newly created Department of Biochemistry in Sheffield, and attracted to his department research workers from both Europe and America. $\mathrm{He}$ is a naturalized British subject, and during the War he has given valuable service in connexion with diet and nutrition. His main contributions to biochemistry are in the field of intermediary metabolism. He showed that the synthesis of urea in the mammalian liver is catalysed by ornithine. This observation led to the formulation of the 'ornithine cycle', according to which ornithine, citrulline and arginine are intermediate stages in the synthesis of urea. His work on the oxidation of carbohydrate in muscle showed that this metabolic process, too, is a cyclic one (known as the 'Krebs cycle'), where a series of organic acids arises periodically.

\section{Prairie Regional Laboratory, Canada : \\ Prof. R. K. Larmour}

Prof. R. K. Larmour, professor of chemistry in the University of Saskatchewan, has been appointed director of the Prairie Regional Laboratory which is to be built in Saskatoon by the Canadian National Research Council. Prof. Larmour served in the War of 1914-18, and following his return from overseas, he graduated from the University of Saskatchewan and carried out postgraduate work in the University of Minnesota, where he was Shevlin fellow. He joined the staff of the University of Saskatchewan in 1927 and has remained there ever since except for a short period when he occupied the chair of milling industry at a mid-western American university. Dr. Larmour has a high reputation in the field of grain research. The Prairie Regional Laboratory will be concerned primarily with investigations into the utilization of agricultural crops. It will be provided with facilities to undertake all phases of laboratory and pilot-plant investigations in this field.

\section{Colonial Development and Welfare Bill}

THE essential feature of the new Bill dealing with Colonial development, which should be of interest to administrators, scientific men and technologists, and all who are concerned with the welfare and advancement of the British Colonial possessions, is that it represents a notable extension of the Colonial Development and Welfare Act of 1940. The extension concerns both the annual provision of funds and the period over which they will be available. Put briefly, whereas the Act of 1940 made available a sum of $£ 5,000,000$ per annum for development and $£ 500,000$ per annum for research, until 1951, the new Act makes available, unless "Parliament otherwise determines", a sum of $£ 120,000,000$ for all purposes during the period 1946-56. A commendable elasticity, which all who are responsible for new schemes whether of research or development will appreciate, is a feature of the new enactment. Thus it is explicitly stated that no time limit is imposed on schemes of research and investigation and up to $£ 1,000,000$ can be spent on such schemes in any one year. For all purposes, up to $£ 17,500,000$ may be expended in any one year.

Few will disagree with these measures. Substantial help for the Colonies has been long overdue. Now, it is reasonable to hope that definite schemes may not only be planned and set in motion but also actually carried through to fruition. Readers of Nature are already familiar with the very diverse developmental, constructional, sociological and research projects which require and are receiving attention under the Colonial Development and Welfare scheme. In particular, it may be pointed out that members of university staffs and of the teaching profession in Britain, as also in the Dominions and in the Colonies, 